\title{
Acute poisoning in children from Jatropha curcas seeds
}

\author{
M C Moshobane, ${ }^{1} \mathrm{MSc}$; C Wium, ${ }^{2} \mathrm{MSc} ; \mathrm{L}$ V Mokgola, ${ }^{3} \mathrm{BSW}$ \\ ${ }^{1}$ Directorate of Biological Invasions, South African National Biodiversity Institute, Pretoria, South Africa \\ ${ }^{2}$ Poison Information Centre, Division Clinical Pharmacology, Faculty of Medicine and Health Sciences, Stellenbosch University, Tygerberg, \\ Cape Town, South Africa \\ ${ }^{3}$ Limpopo Department of Social Development, ga-Kgapane, South Africa
}

Corresponding author: M C Moshobane (moshobanemc@gmail.com)

The semi-evergreen shrub, Jatropha curcas is native to Central and South America, but now occurs worldwide. Four children suffered severe symptoms of abdominal pain, nausea and vomiting after ingesting the seeds of $J$. curcas. These cases support the listing of $J$. curcas as a noxious weed. As a result of this, and a few other incidents, municipal authorities are urged to discourage the use of highly toxic plants such as J. curcas for hedges and garden plants, and to monitor the occurrence of such species. We present a case report about J. curcas poisoning.

S Afr J Child Health 2017;11(3):149-150. DOI:10.7196/SAJCH.2017.v11i3.1401

\section{Case report}

Poisoning from plants is common in South Africa (SA). ${ }^{[1-5]}$ Children are regularly exposed to toxic plants and usually poisoned when plants are mistaken for common, edible plants e.g., Jatropha curcas is often mistaken for nuts. ${ }^{[3-7]}$ Similar cases have been reported in Thailand, India and Israel. ${ }^{[8-10]}$ All of these studies show that children are more susceptible to J. curcas poisoning because of their highly curious nature, which often leads to ingestion of the seeds. There are fewer datasets on paediatric poisoning from developing countries than from developed countries, likely due to underreporting of cases and lack of proper data management systems. ${ }^{[1]]}$ This report deals with four cases of acute J. curcas poisoning in children in Limpopo Province, SA. The immature fruit is small, capsule-like, round and green and becomes dark brown as it matures (Fig. 1). Each fruit contains three black seeds resembling nuts, e.g. peanuts/cashew nuts, that have a sweet taste. ${ }^{[12]}$

Four children aged between 2 and 6 years were playing close to an abandoned yard where the plant grew. A fruit-bearing branch of J. curcas was hanging over the fence and the children collected the fruit and ate the seeds. Shortly after ingesting the fruit, they developed abdominal pain and were rushed to hospital. The lag time before the onset of gastrointestinal (GI) complications varied between 90 and 120 minutes. The GI symptoms that developed included abdominal pain, nausea, vomiting and diarrhoea, as well as a burning sensation in the throat. The patients were treated with intravenous hydration and anti emetic medication and the symptoms resolved within $12-14$ hours. Three of the 4 children were observed for 24 hours and discharged the following day. The 2-year-old child was hospitalised for 7 days owing to prolonged diarrhoea. There is no specific antidote and the lethal dose in humans has not been established. ${ }^{[13]}$
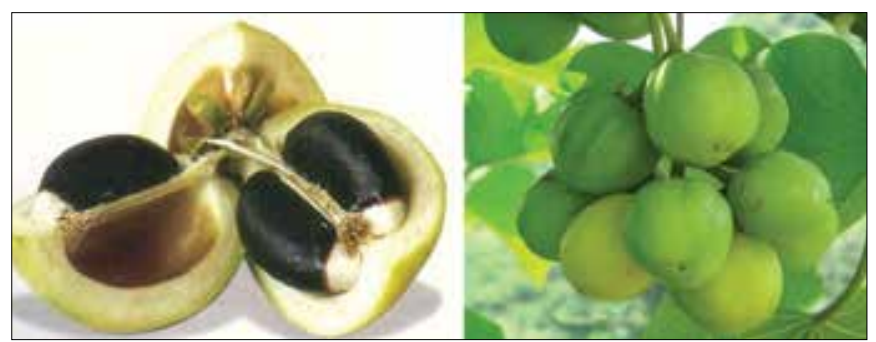

Fig. 1. The fruit of the Jatropha curcas plant. (Photograph courtesy of Annah Ngobeni.)

\section{Discussion}

J. curcas L is a member of the family Euphorbiaceae and also known as a physic nut, purging nut, Barbados nut and purgeerboontjie. It is native to Central and South America, but is now widely distributed in most African countries, India and South East Asia. ${ }^{[14]}$ In SA, it is found mainly in the northern and eastern parts of the country, especially in Limpopo, Mpumalanga and KwaZulu-Natal provinces. ${ }^{[15]}$ It is a drought-resistant perennial plant, widely used as hedges and traditional medicine for ailments such as malaria, oedemas, etc. ${ }^{[6]}$ Research has also recently investigated its potential use in biodiesel production. ${ }^{[16,17]}$

Rural communities cultivate this plant as hedges around gardens and fields. Because of its unpalatability it is not grazed on by cattle. ${ }^{[3]} J$. curcas seeds contain a toxalbumin, curcin, which is 1000 times less toxic than ricin found in Jatropha multifida seeds. ${ }^{[10]}$ The GI effects (purgative activity) are caused by the diterpenoids and curcanoleic acid in the seed oil. ${ }^{[8]}$ GI symptoms vary in severity and include abdominal pain, nausea, vomiting, diarrhoea and burning sensations in the throat. ${ }^{[8-10]}$ Mastication of the seed may also play an important role in the extent of its toxicity. ${ }^{[18]}$ The most effective treatment is symptomatic and supportive care. Most reported cases of J. curcas poisoning occurred in children, with toddlers being at higher risk of severe toxicity, although no fatalities have been reported in humans. ${ }^{[3,8-10]}$ Despite the toxicity of the plant, it is cultivated for various uses, which includes its use as a biofuel. ${ }^{[16]}$ The increased interest and cultivation of $J$. curcas will eventually increase the likelihood of accidental poisoning of children, particularly those in rural areas. ${ }^{[19-22]}$

\section{Conclusion}

This case highlights the need to consider primary public awareness of the toxicity of $J$. curcas. Furthermore, children in areas where the plants occur should be prevented from ingesting the seeds and educated about the dangers of ingesting anything unauthorised by their parents. This case report supports the previous evidence suggesting that $J$. curcas should be considered a noxious weed. We urge municipal agencies to discourage the use of highly toxic plants as hedges or in gardening. In cases where legislation controls the use of this plant, more emphasis should be placed on monitoring and educating people about the dangers of $J$. curcas. ${ }^{[23]}$ Therefore, increased monitoring and surveillance of $J$. curcas populations is recommended. 
Acknowledgements. The South African National Department of Environment Affairs (DEA) through its funding for the South African National Biodiversity Institute (SANBIs)'s Directorate of Biological Invasions supported this work. We thank Mrs Annah Ngobeni for kindly providing logistical information and Dr Samuel Adu-Acheampong for proofreading and correcting this manuscript.

Author contributions. Authors contributed equally to the manuscript.

Funding. This study was funded by the SANBI.

Conflicts of interest. None.

1. Balme K, Clare Roberts J, Glasstone M, Curling L, Mann MD. The changing trends of childhood poisoning at a tertiary children's hospital in South Africa. S Afr Med J 2012;102(3):142-146. https://doi.org/10.7196/samj.5149

2. Du Plooy WJ, Jobson MR, Osuch E, Mathibe L, Tsipa P. Mortality from traditional-medicine poisoning: A new perspective from analysing admissions and deaths at Ga-Rankuwa Hospital. S Afr J Sci 2001;97(3-4):70.

3. Joubert PH, Brown JM, Hay IT, Sebata PD. Acute poisoning with Jatropha curcas (purging nut tree) in children. S Afr Med J 1984;65(18):729-730.

4. Marks CJ, van Hoving DJ. A 3-year survey of acute poisoning exposures in infants reported in telephone calls made to the Tygerberg Poison Information Centre, South Africa. S Afr J Child Health 2016;10(1):43-46. https://doi. org/10.7196/sajch.2016.v10i1.1045

5. Van Wyk B-E, Van Heerden FR, Van Oudtshoorn B. Poisonous Plants of South Africa. Pretoria: Briza Publications, 2002.

6. Mampane KJ, Joubert PH, Hay IT. Jatropha curcas: Use as a traditional Tswana medicine and its role as a cause of acute poisoning. Phyther Res 1987;1(1):5051. https://doi.org/10.1002/ptr.2650010112

7. Wanzala W, Wanjala CCW. Discovering poisonous plants by tasting: The case of children in Mumias Sub-County, Kenya. Arab J Med Aromat Plants 2016;2(2):99-110.

8. Chomchai C, Kriengsunthornkij W, Sirisamut T, Nimsomboon T, Rungrueng W, Silpasupagornwong U. Toxicity from ingestion of Jatropha curcas ('saboo dum') seeds in Thai children. Southeast Asian J Trop Med Public Health 2011;42(4):946-950.

9. Singh RK, Singh D, Mahendrakar AG. Jatropha poisoning in children Med J Armed Forces India 2010;66(1):80-81. https://doi.org/10.1016/s03771237(10)80106-6
10. Levin Y, Sherer Y, Bibi H, Schlesinger M, Hay E. Rare Jatropha multifida intoxication in two children. J Emerg Med 2000;19(2):173-175. https://doi. org/10.1016/s0736-4679(00)00207-9

11. Pocock SJ, Collier TJ, Dandreo KJ, et al. Issues in the reporting of epidemiological studies: A survey of recent practice. BMJ 2004;329(7471):880-883. https://doi. org/10.1136/bmj.38250.571088.55

12. Begg J, Gaskin T. Jatropha curcas L. Poisonous Plants. 1994. http://www. inchem.org/documents/pims/plant/jcurc (accessed 23 November 2016).

13. Micromedex database. Jatropha curcas. Micromedex: Truven Health Analytics, 2017. https://www.micromedexsolutions.com/micromedex2/librarian/ssl/true (accessed 21 July 2017).

14. Fairless D. Biofuel: The little shrub that could - maybe. Nature 2007;449(7163):652-655. https://doi.org/10.1038/449652a

15. Henderson L. South Afr Plant Invaders Atlas (SAPIA). Appl Plant Sci 1998;12:31-32.

16. Pramanik K. Properties and use of Jatropha curcas oil and diesel fuel blends in compression ignition engine. Renew Energy 2003;28(2):239-248. https://doi org/10.1016/s0960-1481(02)00027-7

17. Achten WMJ, Verchot L, Franken YJ, et al. Jatropha bio-diesel production and use. Biomass and Bioenergy 2008;32(12):1063-1084. https://doi.org/10.1016/j. biombioe.2008.03.003

18. Hirai $\mathrm{T}$, Kang $\mathrm{Y}$, Koshino $\mathrm{H}$, et al. Occlusal-masticatory function and learning and memory: Immunohistochemical, biochemical, behavioral and electrophysiological studies in rats. Japan Dent Sci Rev 2010;46(2):143-149. https://doi.org/10.1016/j.jdsr.2009.12.002

19. Sarin R, Sharma M, Sinharay S, Malhotra RK. Jatropha-palm biodiesel blends: An optimum mix for Asia. Fuel 2007;86(10):1365-1371. https://doi. org/10.1016/j.fuel.2006.11.040

20. Van Eijck J, Romijn H, Smeets E, et al. Comparative analysis of key socioeconomic and environmental impacts of smallholder and plantation based Jatropha biofuel production systems in Tanzania. Biomass Bioenergy 2014;61:25-45. https://doi.org/10.1016/j.biombioe.2013.10.005

21. Shah S, Sharma A, Gupta MN. Extraction of oil from Jatropha curcas L. seed kernels by combination of ultrasonication and aqueous enzymatic oil extraction. Bioresour Technol 2005;96(1):121-123. https://doi.org/10.1016/ s0140-6701(05)82158-7

22. Yue GH, Sun F, Liu P. Status of molecular breeding for improving Jatropha curcas and biodiesel. Renew Sustain Energy Rev 2013;26:332-343. https://doi org/10.1016/j.rser.2013.05.055

23. Moshobane MC. Inaugural meeting of the Alien Species Risk Analysis Review Panel. S Afr Netw Coast Ocean Res 2017;214:8. 